\title{
Gambaran Tingkat Kesejahteraan Rumah Tangga Pemilik Rumah Sarang Burung Walet di Desa Topoyo Kecamatan Topoyo
}

\author{
Roswita Yunirna ${ }^{1}$, M. Nur Zakariah Leo ${ }^{2}, \mathrm{Uca}^{3}$ \\ ${ }^{123}$ Universitas Negeri Makassar, Jurusan Geografi \\ Program Studi Pendidikan Geografi \\ Email : yunirnaroswita004@gmail.com
}

(Received: Maret 2019; Reviewed: Maret 2019; Accepted: April 2019; Published: 01 Mei 2019)

Ini adalah artikel dengan akses terbuka dibawah license CC BY-NC-4.0 (C2019 oleh

penulis (https://creativecommons.org/licenses/by-nc/4.0/)

\begin{abstract}
This study aims at 1) Knowing the level of welfare of swallow's nest owners 2) Knowing the level of development of swallow's nest business 3) Knowing the management of swallow nest houses. This research is a qualitative descriptive study. The area that is the object of research is Topoyo Village, Topoyo District, Mamuju Tengah Regency. The population in this study were all swallow nest owners, namely 10 heads of families. Data collecting techniques are carried out through observation, interview and documentation techniques. The results showed that swallow nest owners were generally productive 30-39 years old and all male sexes with marital status were married and the level of education of the average swallow nest homeowner was junior and senior high school graduates. 1) Revenue of the owner of the bird's nest wallet Didesa Topoyo Topoyo Subdistrict Central Mamuju Regency through the indicator of welfare level according to BPS, in 2005 high income that is equal to >10,000,000 / month or >120,000,000/year, based on sales respondents income from swallow nest, namely 13,000,000, - / kg in the harvest period 3-4 times per year as much as> $6 \mathrm{~kg}$ in one harvest period or $>$ 234,000,000, - 312,000,000. 2) Increasing the welfare of swallow nest owners can be seen from before and after establishing a swallow nest house, namely. There are (2) respondents who have to pay the loan in the form of installments to the bank so that they have not shown their level of welfare from swallow birds. which causes air pollution and noise pollution.
\end{abstract}

Keywords: Swallow's Nest; Welfare Level

\section{ABSTRAK}

Penelitian ini bertujuan untuk 1) Mengetahui tingkat kesejahteraan pemilik sarang wallet, 2) Mengetahui tingkat pengembangan bisnis sarang wallet, 3) Mengetahui pengelolaan rumah sarang walet. Penelitian ini adalah penelitian deskriptif kualitatif. Daerah yang menjadi objek penelitian adalah Desa Topoyo, Kecamatan Topoyo, Kabupaten Mamuju Tengah. Populasi dalam penelitian ini adalah semua pemilik sarang walet, yaitu 10 kepala keluarga. Teknik pengumpulan data dilakukan melalui teknik observasi, wawancara dan dokumentasi. Hasil penelitian menunjukkan bahwa pemilik sarang walet umumnya berusia produktif 30-39 tahun dan semua jenis kelamin laki-laki dengan status perkawinan sudah menikah dan 
tingkat pendidikan rata-rata pemilik sarang walet adalah lulusan SMP dan SMA. 1) Pendapatan pemilik dompet sarang burung Didesa Topoyo Topoyo Top Kabupaten Maтuju Tengah melalui indikator tingkat kesejahteraan menurut BPS, pada tahun 2005 pendapatan tinggi yang sama dengan > 10.000.000 / bulan atau> $120.000 .000 /$ tahun, berdasarkan responden penjualan Penghasilan dari sarang walet, yaitu 13.000.000, - / kg pada periode panen 3-4 kali per tahun sebanyak> 6 $\mathrm{kg}$ dalam satu periode panen atau> 234.000.000, - 312.000.000. 2) Meningkatkan kesejahteraan pemilik sarang walet dapat dilihat dari sebelum dan sesudah membangun rumah sarang walet, yaitu. Ada (2) responden yang harus membayar pinjaman dalam bentuk angsuran ke bank sehingga mereka belum menunjukkan tingkat kesejahteraan mereka dari burung walet. yang menyebabkan polusi udara dan polusi suara.

Kata Kunci: Sarang Burung Walet; Tingkat Kesejahteraan

\section{PENDAHULUAN}

Burung walet (Collocalia sp) adalah salah satu jenis burung yang menghasilkan sarang bernilai ekonomis tinggi.Nilai ekonomis yang dimiliki sarang walet ini adalah alasan utama mengapa usaha sarang walet banyak diminati oleh masyarakat. Dengan perkembangan pengetahuan dan teknologi budidaya burung waletkini telah dapat dibudidayakan dibangunan rumah yang khusus dirancang mirip dengan ekosistem gua alami dengan suhu 24oC-26oC.

Di Desa Topoyo sarang burung walet merupakan hal yang tergolong masih baru sejak sepuluh tahun terahkir. Tingginya harga yang ditawarkan dan banyaknya permintaan membuat menjamurnya usaha budidaya burung walet. Karna manfaat dari sarang burung walet yang besar membuat sarangnya menjadi komoditas ekspor yang eksklusif. Sehubungan dengan uraian di atas, sarang burung walet tentu memiliki pengaruh terhadap kehidupan ekonomi masyarakat yaitu peningkatkan kesejahtraan masyarakat. Berdasarkan hal tersebut mendorong peneliti untuk meneliti "Potret Tingkat Kesejahteraan Rumah Tangga Pemilik Sarang Burung Walet Di Desa Topoyo, Kecamatan Topoyo, Kabupaten Mamuju Tengah, Provinsi Sulawesi Barat".

Pentingnya penelitian untuk mengetahui mengetahui tingkat kesejahteraan pemilik sarang burung walet, mengetahui peningkatan kesejahteraan pemilik sarang burung walet, mengetahui pengelolaan sarang burung walet .

Burung walet merupakan burung pemakan serangga yang bersifat aerial dan suka meluncur. Burung ini berwarna gelap, terbangnya cepat dengan ukuran tubuh sedang/kecil, dan memiliki sayap berbentuk sabit yang sempit dan runcing, kakinya sangat kecil begitu juga paruhnya dan jenis burung ini tidak pernah hinggap di pohon. Burung walet mempunyai kebiasaan berdiam di guagua atau rumah-rumah yang cukup lembab, remang-remang sampai gelap dan menggunakan langit-langit untuk menempelkan sarang sebagai tempat beristirahat dan berbiak.terdiri dari tiga spesies yaitu walet sarang putih, walet sarang hitam, walet linci. Walet membuat sarang menggunakan air liurnya, Sarang yang dihasilkan tersebut bersifat edible nest atau sarang yang dapat dimakan dan biasa disebut dengan edible bird's nest (EBN). komposisi EBN dari genus Collocalia Indonesia dan Malaysia terdiri atas karbohidrat (25,62$27,26)$, protein $(62-63 \%)$, lipid $(0,14-1,28 \%)$ dan abu (2,1\%). faktor-faktor yang mempengaruhi kehidupan walet adalah suhu, kelembaban, cahaya, keamanan, pemilihan lokasi yang sesuai, penyiapan sarana dan peralatan, memperhatikan bentuk dan konstruksi gedung dan menjaga dari hama dan penyakit.

Pengertian sejahtera adalah suatu keadaan yang aman, sentosa, dan makmur. Dalam arti lain jika kebutuhan akan keamanan, keselamatan dan kemakmuran ini dapat terpenuhi, maka akan terciptalah 
kesejahteraan. Menurut Undang-undang No 11 Tahun 2009, Kesejahteraan Masyarakat, kesejahteraan masyarakat adalah kondisi terpenuhinya kebutuhan material, spiritual, dan sosial warga negara agar dapat hidup layak dan mampu mengembangkan diri, sehingga dapat melaksanakan fungsi sosialnya.

Dari Undang-Undang di atas dapat kita cermati bahwa ukuran tingkat kesejahteraan dapat dinilai dari kemampuan seorang individu atau kelompok dalam usahanya memenuhi kebutuhan material dan spiritual nya. Indikator tingkat kesejahteraan terdiri dari jumlah modal, jumlah pendapatan, peralatan yang dibutuhkan, jumlah komsumsi atau pengeluaran rumah tanngga, keadaan tempat tinggal, fasilitas tempat tinggal, kesehatan, pendidikan, fasilitas transportasi yang dimiliki.

Berdasarkan indikator tersebut maka dapat ditentukan tingkat kesejahteraan rumah tangga pemilik sarang burung walet menjadi tiga bagian Tingkat Kesejahteraan Tinggi (Kaya), Tingkat Kesejahteraan Sedang, Tingkat Kesejahteraan Rendah. Secara sederhana, sebagai gambaran awal dalam melanjutkan penelitian ini adalah sebagian besar penduduk didesa yang denganbudi daya burung walet.yang menjadi pusat perhatian dalam penelitian ini adalah tingkat kesejatraan yang di miliki oleh setiap masyarakat yang memiliki sarang burung walet.

\section{METODE}

Penelitian ini dilakukan di Desa Topoyo, Kecamatan Topoyo, Kabupaten Mamuju Tengah. Populasi dalam penelitian ini adalah seluruh jumlah sampel yaitu 10 kepala keluarga pemilik sarang burung walet. metode pengambilan sampel yang digunakan dalam penelitian ini adalah sampel jenuh dimana subjek penelitiannya adalah keseluruhan masyarakat yang berprofesi sebagai pemilik sarang burung walet. Penelitain ini merupakan penelitian deskriptif kualitatif yaitu penulis berusaha menggambarkan secara apa adanya mengenai potret tingkat kesejahteraan rumah tangga pemilik sarang burang walet.

Hasil data yang diperoleh dari lapangan melalui observasi dan wawancara dengan menggunakan kuesioner dan informasi dokumen berupa gambar tentang potret tingkat kesejahteraan pemilik sarang burung walet, tingkat perkembangan usaha, pengelolaan sarang burung walet yang ada di Desa Topoyo. Data yang telah dikumpulkan oleh peneliti selanjutnya akan digambarkan dan diuraikan berdasarkan indicator tingkat kesejahteraan yang telah disimpulkan. Maka berdasarkan uraian indikator dari tersebut maka dapat ditentukan tingkat kesejahteraan pemilik sarang burung wallet diDesa Topoyo yaitu tingkat kesejahteraan tinggi, tingkat kesejahteraan sedang dan tingkat kesejahteraan rendah.

\section{HASIL DAN PEMBAHASAN}

\section{Gambaran Umum Lokasi Penelitian}

Kabupaten Mamuju Tengah terletak di Provinsi Sulawesi Barat pada posisi 1047' 82' - 20 17' 31" Lintang Selatan dan 1190 08' 13" - 1190 24' 08" Bujur Timur. Kabupaten Mamuju Tengah memiliki luas wilayah sebesar 3.014,37 $\mathrm{km} 2$ yang secara administratif terbagi ke dalam lima kecamatan. Kecamatan yang paling luas wilayahnya adalah Kecamatan Karossa dengan luas 1.093,54 km2 atau 36,28 persen dari luas wilayah Kabupaten Mamuju Tengah. Sementara, kecamatan dengan luas wilayah terkecil adalah Kecamatan Pangale dengan luas 115,69 km2 atau 3,84 persen. Dibentuk berdasarkan UU No. 4 tahun 2013, pada 14 Desember 2012. Dengan Jumlah penduduk, 105.495 jiwa dengan luas wilayah $3.014,37 \mathrm{~km} 2$, terdiri dari 5 kecamatan, 56 desa/kelurahan. Kabupaten Mamuju Tengah mempunyai batas-batas wilayah yaitu Sebelah Utara berbatasan dengan berbatasan dengan Kabupaten Mamuju Utara, Sebelah Selatan berbatasan dengan Kabupaten Mamuju, Sebelah Barat berbatasan dengan Selat Makassar, dan Sebelah Timur berbatasan dengan provinsi Sulawesi selatan. 


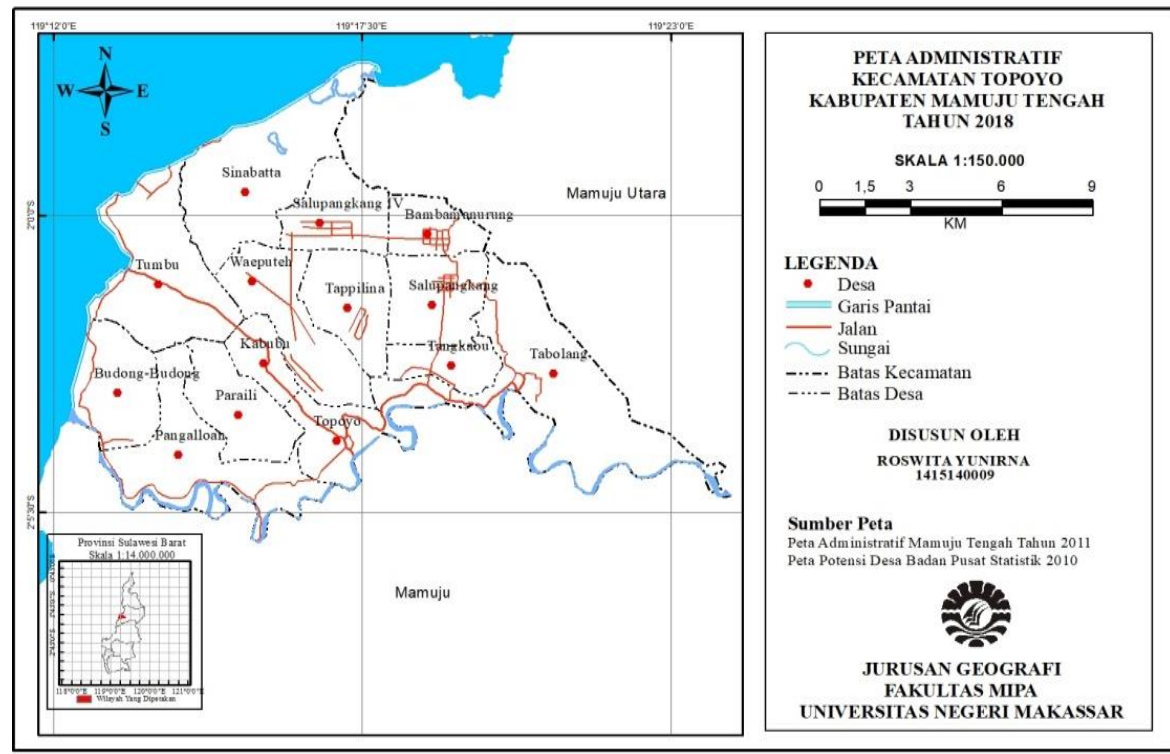

Gambar 1. Peta Lokasi Penelitian

\section{Hasil}

Seluruh responden merupakan penduduk asli setempat. Total responden sebanyak 10 orang.secara khusus empat responden dengan usia produktif yaitu 30-39 tahun dari total populasi dan semua responden berstatus menikah. Ada 8 responden beragama islam dan 2 beragama hindu. Dengan jumlah keluarga ratarata adalah 3 orang.

a. Indikator tingkat kesejahteraan

1. Jumlah modal

Tabel 1 Biaya Pembangunan Sarang Walet

\begin{tabular}{cccc}
\hline No & Besarnya Biaya $(\mathbf{R p})$ & $\mathbf{f}$ & $\mathbf{\%}$ \\
\hline 1. & $10.000 .000-100.000 .000$ & 7 & 70 \\
2. & $>100.000 .000$ & 3 & 30 \\
\hline & Total & $\mathbf{1 0}$ & $\mathbf{1 0 0}$ \\
\hline
\end{tabular}

Data pada Tabel 1 diatas yaitu sebanyak 7 responden atau $70 \%$ dapat diketahui modal pembangunan sarang walet yaitu $\mathrm{Rp}$
10.000.000 - Rp 100.000.000 dan sebanyak 3 responden dengan modal pembangunan sarang walet yaitu $\mathrm{Rp}>100.000 .000$.

\section{Jumlah pendapatan}

Tabel 2. Penghasilan Bersih Responden

\begin{tabular}{cccc}
\hline No & Pendapatan & f & \% \\
\hline 1. & $<10.000 .000$ & 1 & 10 \\
2. & $10.000 .000-100.000 .000$ & 1 & 10 \\
3. & $100.000 .000-500.000 .000$ & 6 & 60 \\
4. & $500.000 .000-1.000 .000 .000$ & 2 & 20 \\
\hline & Jumlah & $\mathbf{1 0}$ & $\mathbf{1 0 0}$ \\
\hline
\end{tabular}

Sumber : Data primer olahan 2018 
Data pada Tabel 2 jumlah pendapatan bersih pemilik sarang burung walet sebanyak 1 responden atau $10 \%$ diketahui memiliki penghasilan bersih terkecil sebesar $\mathrm{Rp}<10.000 .000$ dan sebanyak 1 responden dengan penghasilan bersih sebesar
Rp10.000.000- Rp100.000.000 dan sebanyak 6 responden atau $60 \%$ memiliki penghasilan sebesar Rp100.000.000-Rp 500.000.000 serta sebanyak 2 responden atau $20 \%$ diketahui memiliki penghasilan sebesar Rp500.000.000-Rp 1.000.000.000.

3. Jumlah Komsumsi Atau Pengeluaran Rumah Tangga

Tabel 3 Pengeluaran Pangan Dan Nonpangan Responden

\begin{tabular}{|c|c|c|c|}
\hline No & Pengeluaran & $\mathbf{f}$ & $\%$ \\
\hline 1. & $10.000 .000-50.000 .000$ & 3 & 30 \\
\hline 2. & $50.000 .000-100.000 .000$ & 7 & 70 \\
\hline & Jumlah & 10 & 100 \\
\hline
\end{tabular}

Data pada Tabel 3 dengan Total komsumsi atau pengeluaran pangan dan nonpangan rumahtanggapemilik rumah sarang burung walet sebanyak 3 responden atau $30 \%$ diketahui memiliki pengeluaran sebesar Rp10.000.000-Rp50.000.000 dan sebanyak 7 responden memiliki pengeluaran sebesar
Rp50.000.000 - Rp 100.000.000.

4. Penerimaan Dari Sarang Burung Walet Perkembangan ditinjau dari penerimaan dari hasil pemanenan dan penjualan sarang burung walet dalam satukali jual dapat dilihat dari tabel berikut:

Tabel 3. Penerimaan Hasil Sarang Walet dengan Modal Sendiri Responden

\begin{tabular}{|c|c|c|c|c|c|c|c|}
\hline \multirow[b]{2}{*}{ No } & \multirow{2}{*}{$\begin{array}{c}\text { Respon } \\
\text { den }\end{array}$} & \multirow{2}{*}{$\begin{array}{c}\text { Jumlah } \\
\text { Sarang } \\
\text { Walet } \\
\text { (Kg) }\end{array}$} & \multicolumn{3}{|c|}{ Modal Awal } & \multirow{2}{*}{$\begin{array}{l}\text { Penjualan } \\
\quad \text { (thn) }\end{array}$} & \multirow{2}{*}{$\begin{array}{c}\text { Pendapatan } \\
\text { (thn) }\end{array}$} \\
\hline & & & Gedung & Peralatan & Total & & \\
\hline 1 & I & 2 & $80.000 .000,-$ & 2.000.000,- & $822.000 .000,-$ & $35.000 .000,-$ & $35.000 .000,-$ \\
\hline 2 & II & 132 & 180.000.000,- & 2.000.000,- & 182.000.000,- & 1.716.000.000,- & 1.534.000.000, \\
\hline 3 & & & & & 92.000.000,- & $312.000 .000,-$ & $220.000 .000,-$ \\
\hline 4 & IV & 26 & 100.000.000,- & 2.000.000,- & 102.000.000,- & 338.000.000,- & 236.000.000,- \\
\hline 5 & $\mathrm{~V}$ & 28 & 149.000.000,- & 2.000.000,- & 151.000.000,- & 365.000.000,- & 213.000.000,- \\
\hline 6 & VI & 1 & 100.000.000,- & 2.000.000,- & 102.000.000,- & 13.000.000,- & $-89.000 .000,-$ \\
\hline 7 & VII & 72 & $150.000 .000,-$ & 2.000.000,- & 152.000.000,- & $936.000 .000,-$ & 784.000.000,- \\
\hline 8 & VIII & 9 & 100.000.000,- & 2.000.000,- & 102.000.000,- & 117.000.000,- & 15.000.000,- \\
\hline 9 & IX & 6 & & 2.000.000,- & 107.000.000,- & 78.000.000,- & $-29.000 .000,-$ \\
\hline 10 & $X$ & 1 & 100.000.000,- & 2.000.000,- & 102.000.000,- & 13.000.000,-- & $-89.000 .000,-$ \\
\hline
\end{tabular}

Sumber : olahan data primer 2018

\section{Pembahasan}

1. Potret Tingkat Kesejahteraan Rumah Tangga Pemilik Sarang Burung Walet Potret atau gambaran tingkat kesejahteraan rumah tangga pemilik sarang burung walet dikecamatan Topoyo diukur dari beberapa indikator diantaranya pendapatan, komsumsi dan pengeluaran rumah tangga, keadaan tempat tinggal, fasilitas tempat tinggal, ksesehatan, pendidikan dan fasilitas trasportasi. Berdasarkan pendapatan responden pemilik 
rumah sarang burung walet yang berada didesa Topoyo menunjukkan bahwa setiap responden memiliki penghasilan pertahun yang tinggi yaitu dengan pendapatan lebih dari $>10.000 .000$ dengan jumlah penghasilan terkecil sebesar $\mathrm{Rp}$ 37.000.000,- dan terbesar sebesar $\mathrm{Rp}$ 1.716.000.000,- . berdasarkan komsumsi dan pengeluaran rumah tangga menunjukkan bahwa pengeluaran pangan dan nonpangan dari responden dengan pengeluaran $>5.000 .000$, dengan jumlah pengeluaran terkecil sebesar Rp 28.297.560,- Dan yang terbesar sebesar Rp330.537.960,-.

Berdasarkan keadaan tempat tinggal responden secara umum satu (1) responden dengan keadaan rumah yang Rumah setengah batudengan atap rumah seng dan dinding rumah papan dengan lantai tembok/ semen dan fasilitas MCK bersama. Dan secara khusus Sembilan (9) responden dengan keadaan rumah permanen atau Rumah permanen dari batudengan atap seng/tegel dan dinding rumah terbuat dari batu dan lantai tegel dan fasilitas MCK sendiri, sebanyak sepuluh atau seluruh responden memiliki sumber penerangan berasal dari listrik PLN. Berdasarkan fasilitas tempat tinggal secara umum sebanyak sepuluh (10) atau seluruh responden memiliki fasilitas elektronik lengkap seperti TV berwarna, radio, ketersediaan listrik dan lain-lain . Berdasarkan kesehatan sebanyak sepuluh (10) atau seluruh responden mudah mendapatkan fasilitas dan pelayanan rumah sakit. Berdasarkan pendidikan yang dimiliki responden yaitu sebanyak sepuluh (10) atau seluruh responden mudah memasukkan anak bangku sekolah (SD, SMP, SMA dan perguruan tinggi negeri ). Berdasarkan fasilitas trasportasi yaitu sebanyak delapan (8) responden memiliki kendaraan pribadi yaitu mobil dan dua (2) responden memiliki motor dengan status kepemilikan kendaraan yaitu milik sendiri.

\section{Peningkatan Kesejahteraan Pemilik Sarang Burung Walet}

Tidak semua yang memiliki sarang walet menggunakan modal sendiri ( dapat dilihat pada tabel 4.18 dan tabel 4.19) maka ada 3 responden yang belum menunjukkan peningkatan kesejahteraan. Maka 2 responden yang belum dapat mengembalikan modal awal dan masih harus membayar angsuran pinjaman dibank untuk biaya pembangunan gedung setiap bulannya. Sehingga 2 responden ini belum menunjukkan tingkat kesejahteraan dari usaha sarang burung walet. Dan 1 responden yang juga belum menunjukkan peningkatan kesejahteraan tetapi tidak membayar angsuran dibank karna membangunan rumah sarang burung walet dengan dengan modal sendiri.Sehingga ketiga responden ini belum dapat mengembangkan pembangunan rumah sarang burung walet.

\section{Pengelolaan Sarang Burung Walet}

Pemeliharaan sarang burung Walet Agar diperoleh kualitas sarang walet yang baik diperlukan pengelolan dan pemeliharaan . Usahausaha tersebut meliputi beberapa hal berikut ini:

Mengatur dan mempertahankan kondisi gedung sebaik mungkin. Kondisi dalam gedung walet perlu diperhatikan seperti kelembapan dan suhu.

Melakukan pemberantasan dan pencegahan serangan hama seperti burung hantu dan tikus yang dapat mengganggu kehidupan walet. Bagian dasar bangunan rumah sarang burung walet dibuat dengan melapisi seng yang polos yang rapat kedinding setinggi 1 meter untuk menghindari gangguan dari tikus. Dengan demikian, walet dapat hidup tenang dan aman serta sarang walet yang dihasilkan tidak rusak oleh pengganggu tersebut.

Tidak melakukan aktifitas yang menimbulkan polusi udara dan polusi suara, seperti pembakaran sampah disekitar rumah guna menjaga kenyamanan burung walet.

Rutin memanen sarang setiap 1 bulan agar populasi burung walet dapat bertambah.

Menyemprotkan kotoran burung walet pada dinding rumah sarang walet pada rumah sarang walet yang baru dibagun.

Memasang sarang tiruan mirip sarang burung walet pada rumah sarang walet yang baru dibagun.

\section{SIMPULAN DAN SARAN}

\section{Kesimpulan}

Berdasarkan hasil analisis data, maka dapat disimpulkan sebagai berikut :

1. Pendapatan pemilik rumah sarang burung wallet Didesa Topoyo Kecamatan Topoyo Kabupaten Mamuju Tengah melalui indicator tingkat kesejahteraan menurut BPS, tahun 2005 pendapatan tinggi yaitu sebesar $>10.000 .000,-\quad$ /bulan atau 
$>120.000 .000,-/$ tahun, berdasarkan pendapatan responden penjualan dari sarang walet yaitu $13.000 .000,-/ \mathrm{kg}$ dalam masa panen 3-4 kali pertahun sebanyak >6 kg dalam 1 kali masa panen atau >234.000.000,-312.000.000,-. Maka berdasarkan pendapatan responden tingkat kesejahteraan yang dimiliki tinggi yaitu $>10.000 .000 /$ bulan,atau $>120.000 .000,-/$ tahun.

2. peningkatan kesejahteraan pemilik sarang burung walet dapat dilihat dari sebelum dan sesudah mendirikan rumah sarang burung walet yaitu sangatlah didukung oleh ketersediaan modal dan usia rumah sarang burung walet .Dalam pembangunan sarang modal sangatlah berperan. Ada (2) responden yang haeus membayar pinjaman berupa angsuran ke bank sehingga belum menunjukkan tingkat kesejahteraannya dari usaha burung walet.

3. pengelolaan sarang burung walet perlu diperhatikan untuk meningkatkan produksi sarang burung walet seperti memperhatikan suhu ruangan, penanggulangan hama, dan Tidak melakukan aktifitas yang menimbulkan polusi udara dan polusi suara.

\section{Saran}

Berdasarkan kesimpulan yang dikemukakan maka penulis menyarankan:

1. Pemerintah seharusnya dapat melakukan pengawasan dampak berupa kebisingan suara dari penangkaran sarang burung walet terhadap lingkungan agar masyarakat lebih nyaman.

2. Dalam pembuat kebijakan pemerintah seharusnya lebih tegas dalam membuat sebuah aturan tentang perizinan pembangunan rumah sarang burung walet dan keharusan membayar pajak.

3. Pemilik rumah sarang burung walet seharusnya membatasi waktu membunyikan twiter.

4. Penelitian selanjutnya diharapkan melakukan penelitian yang lebih mendalam terhadap objek permasalahan ini.

\section{DAFTAR RUJUKAN}

Nugroho taufik rofi. 2014. Tingkat Kesejahteraan Rumah Tangga Pengrajin Industri Bata Merah Dikecamatan Pataruman Jawa Barat. Skripsi. Universitas Negeri Yogyakarta.

Adi, Isbandi Rukmiyanto 2013. Kesejahteraan Sosial Ekonomi.

Adiwibawa, E. 2000. Pengelolaan Rumah Walet. Yogyakarta. Kanisius.

Aulia,Dina. 2017. Analisis Tingkat Kesejahteraan Rumah Tangga Pengrajin Batik Didesa Simbang Kulon Kecamatan Buarang Kabupaten Pekalongan. Skripsi. Universitas Islam Negeri Sunan Kalijaga Yogyakarta.

Andi Angger S, Siti Rochaenianalisis , Achmad Tjachja N. 2013. Tingkat Kesejahteraan Rumah Tangga Petani Ikan Hias Air Tawar Di Kelurahan Cipedak Kecamatan Jagakarsa Kota Madya Jakarta Selatan.Jurnal Agribisnis, Vol. 7, No. 1, Juni 2013, [ 59 - 76 ] Issn : 1979-0058

Hans Ivander Joy Simanungkalit. 2015. Analisis Dampak Pengusahaan Sarang Burung Walet di Kota Rantauprapat Kabupaten Labuhan Batu. Skripsi. Departemen Ilmu Politik Fakultas Ilmu Sosial Dan Ilmu Politik Universitas Sumatera Utara Medan 2015.

Hartoyo, Noorma Bunga Aniri. 2010. Analisis Tingkat Kesejahteraan Keluarga Pembudidaya Ikan Dan Nonpembudidaya Ikan Dikabupaten Bogor. Januari 2010, P : 64-73 Vol. 3, No. 1

Joko Mulyono. 2010. Kajian Tentang Usaha Sarang Burung Walet Di Kabupaten Sampang (Tinjauan Ekonomis). Skripsi. Fakultas Pertanian. Universitas Pembangunan Nasional "Veteran" Jawa Timur.

Kementrian Kehutanan dan Perkebunan. 1999. Pengelolaan Burung Walet (Collocalia) di Habitat Alami (In-Situ) dan Hbiitat Buatan (Ex-Situ). Kepmenhut Nomor 449/Kpts- II/1999, Jakarta. 